\title{
Om erfaringer med podcasts i universiteternes undervisning
}

\section{Simon B. Heilesen}

Lektor, mag.art.

Roskilde Universitet

simonhei@ruc.dk

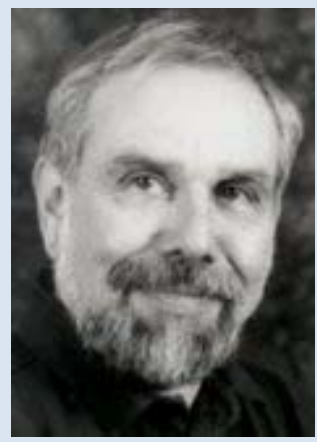

Simon B. Heilesen er lektor i netbaseret kommunikation ved Institut for Kommunikation, Virksomhed og Informationsteknologier, Roskilde Universitet. Aktuelt koordinerer han opbygningen af universitetets IKT-Kompetenceudvikling og deltager desuden $i$ ledelsen af ELYK-projektet, der handler om netbaseret efteruddannelse af medarbejdere i små og mellemstore virksomheder i yderområder (http://www.elyk.dk). 


\section{Abstract}

I disse år investerer de videregående uddannelser ganske mange ressourcer $i$ at understøtte undervisningen med audio- og videooptagelser. Især podcasting er i vælten, og det er en almindelig antagelse både på læreanstalterne og i den offentlige debat, at podcasting er til gavn for de studerende. Men hvor meget er forventninger, og hvor meget er hårde kendsgerninger? Det søger denne artikel at give et indtryk af på baggrund af et bredt udvalg af den videnskabelige litteratur, som beskæftiger sig med målinger af virkningen af at inddrage podcasting i undervisningen. Artiklen ser på de studerendes generelle oplevelse af at have at have lyd- og videooptagelser til rådighed; på målinger af de studerendes resultater ved prøver; samt på nogle af de konsekvenser, som podcasting kan have for tilrettelæggelsen af undervisningen.

\section{Indledning}

Med lanceringen i 2009 af iTunes University i en række europæiske lande, herunder Danmark, er podcasting for alvor kommet på dagsordenen for elæring. Flere danske universiteter producerer rutinemæssigt podcasts, og andre er på vej. Podcasting blev et uddannelsespolitisk tema (med vægt på demokratisering og effektivisering) allerede for nogle år siden (Socialdemokraterne, 2007), hvor der udspandt sig en kortvarig, engageret debat (Blædel, 2007). Karakteristisk for denne, og i det hele taget for meget af det, der er skrevet om podcasting, er, at der er mange forventninger til og formodninger om den nye teknologis velsignelser, men endnu ikke synderligt mange forskningsresultater til at underbygge dem. Med udsigt til at der i de kommende år vil blive investeret ganske mange ressourcer i podcasting på universiteterne, kan det derfor være interessant at skabe sig et overblik over, hvad der egentlig findes af dokumentation af det læringsmæssige udbytte af podcasting. Det vil denne artikel forsøge at bidrage til.

I snæver forstand indebærer podcasting download (hentning) ved hjælp af syndikering (automatiseret ajourføring) af lydfiler fra internettet. I den aktuelle sammenhæng vil begrebet imidlertid blive brugt bredt om download af filer med optagelser af lyd, stillbilleder og video (vodcasting), hvad enten det foregår automatisk ved hjælp af et feed, eller om brugeren manuelt henter filen i et arkiv eller på en webside. Undtaget er dog streaming video og videokonference, som begge ikke uden videre lader sig overføre fra en computer til en hvilken som helst mobil lyd-/videoafspiller. Endvidere skelnes der mellem podcast(s), som er de produkter, der distribueres, og podcasting, som er teknologien til at distribuere produkterne, eller i bred forstand: mediet. 
Universitetspodcasts er et omfattende begreb. Vogele \& Gard (2006) skelner mellem administrative podcasts (fx information til studiestartere eller potentielle studerende), podcasts af specialforelæsninger ( $\mathrm{fx}$ festforelæsninger, gæsteforelæsninger m.m.), samt undervisnings-podcasts (til den skemalagte undervisning). Det er denne sidste kategori, som diskuteres i det følgende.

Målgruppen for undervisningspodcasts er normalt de studerende ved den pågældende undervisningsinstitution. Når først materialet ligger offentligt tilgængeligt på nettet, kan det imidlertid få stor udbredelse og blive et element i markedsføringen af universitetet. Der findes flere eksempler på, at undervisning, som egentlig ikke var tænkt populariserende, har opnået stor og uventet succes (Bongey et al., 2006; Hürst et al., 2007; Malan, 2007).

Podcasts er en meget bred betegnelse for lyd-/video-produktioner, der kan være af vidt forskellig art. Derfor giver det ikke mening at diskutere effekten af podcasts generelt. Den skal altid forstås i en uddannelses- eller undervisningssammenhæng. Undervisningspodcasts er typisk produceret af underviseren eller institutionen og kan udgøre optagelser af hele undervisningsforløb (normalt forelæsninger) eller være særligt tilrettelagte produkter, som præsenterer et udvalgt, vigtigt og/eller vanskeligt stof, eller som resumerer et pensum eller opsummerer en fremlæggelse. Podcasts med bedømmelser af studerendes opgaver forekommer også (France \& Wheeler, 2007; Lazzari, 2009; Ribchester et al., 2008). Studenterinddragende eller studenterproducerede podcasts er en anden hovedkategori. Den forekommer fx i form af podcasts, der uddyber et emne gennem en dialog mellem studerende og underviser (Nathan \& Chan, 2007) eller udgør en opgavebesvarelse (Edirisingha et al., 2007a; Frydenberg, 2006).

\section{Podcaststudier}

Podcasting er et meget nyt begreb. Det teknologiske fundament blev bragt til veje i år 2000, mens selve betegnelsen blev lanceret i 2004 (Cochrane, 2005, s. 11), samtidig med at interessen for den nye teknologi voksede så eksplosivt, at podcasting i 2005 blev valgt til årets nye ord af New Oxford American Dictionary (Oxford University Press, 2005).

Anvendelse af podcasting i undervisningen tog fart i 2005 med benovet optimisme over de nye muligheder (Campbel, 2005), og siden er der udgivet mængder af litteratur om emnet. Men det ligger i sagens natur, at det er en "ung" litteratur, forstået på den måde, at der typisk mangler den distance og det overblik, som længere tids grundige erfaringer med en teknologi kan tilvejebringe. I hovedtræk (og med overlap) fordeler den akademiske litteratur om podcasting sig på vejledninger i brug af 
teknologien, visioner om teknologiens muligheder og konkrete undersøgelser af anvendelser af podcasting. Det er denne sidste kategori, som udgør grundlaget for nærværende artikel.

Khe Foon Hew (2008) har for nyligt publiceret et godt litteraturreview, som afdækker hovedtemaer og metoder i forskningen i undervisningspodcasting. Nærværende artikel supplerer Hews litteraturliste på området effekt af undervisningspodcast, og den går mere i detaljer med hensyn til karakteren af den målte effekt. Litteraturen er indsamlet med udgangspunkt i Hew, og der er suppleret gennem systematisk søgning i ti akademiske databaser, med søgninger i Google Scholar samt rapporter fra en iTunes-pionerinstitution (se Appendiks A for detaljer). Det er forfatterens vurdering, at der er identificeret et så bredt udvalg af materiale, at det kan give et afbalanceret indtryk af, hvordan podcasting evalueres, og hvad tendensen i resultaterne er. Men det påstås naturligvis ikke på nogen måde, at litteratursøgningen (pr. ultimo januar 2009) har givet en udtømmende eller fuldt ud repræsentativ dækning af emnet. Alle analyserede og relevante udgivelser er medtaget $\mathrm{i}$ litteraturlisten til denne artikel, også selvom der ikke direkte refereres til dem i brødteksten.

De fremfundne artikler er ud fra gennemlæsning bedømt for relevans, og de er derefter analyseret ud fra en række parametre, som med udgangspunkt i Hews undersøgelse og forfatterens egen vurdering kan tænkes at have betydning for forståelsen af de resultater, der fremlægges (se Appendiks B for detaljer).

Sammenfattende kan det konstateres, at hovedparten af undersøgelserne kun omfatter ét semesters undervisning eller dele af et semester. Kun ganske få forløb strækker sig over flere semestre, heri ikke indregnet de undersøgelser, der drager sammenligninger med tidligere semestre, hvor podcasting ikke blev anvendt. Mest omfattende af de længerevarende forsøg er den massive, flerårige anvendelse af podcasting på Duke University, som imidlertid kun er rapporteret på et ret generelt niveau (Belanger, 2005; 2007a; 2007b; Earp et al., 2006). De relativt korte undervisningsforløb betyder, at materialet stort set kun gengiver umiddelbare indtryk, og at der ikke foreligger et bredt og troværdigt materiale om effekten af podcasting over tid. Dette forhold gør det umuligt at vurdere den reelle rækkevidde af de "bløde" virkninger i form af forbedret studiemiljø, som ofte fremhæves af de studerende i deres evalueringer af podcast-forsøgene.

Den indsamlede litteratur er international og stammer primært fra engelsksprogede peer reviewede tidsskrifter og konference-proceedings; sekundært fra engelsksprogede samleværker og rapporter. Denne 
sproglige afgrænsning, som er praktisk begrundet, er medvirkende til, at den overvejende del af de undersøgte undervisningsforløb stammer fra engelsktalende lande, flest fra USA, men også en del fra Storbritannien og Australien. Podcast-forsøgene, som omtales i det følgende, skal altså forstås i lyset af en angelsaksisk undervisningstradition, hvor instruktivistisk pædagogik er mere fremherskende, end den er herhjemme. Det kan betragtes som en svaghed ved nærværende undersøgelse, at den ikke systematisk har forsøgt at inddrage erfaringer udgivet på de øvrige hovedsprog.

Den undersøgte litteratur dækker fagligt bredt, idet der dog er en klar overvægt af datalogi-kurser. Der findes desuden flere undersøgelser inden for biovidenskabelige fag, geografi, handelsfag og sprogfag, samt nogle få undersøgelser inden for biblioteksvidenskab, ingeniørstudier, jura, sygepleje og psykologi. Hovedparten af undersøgelserne handler om undervisning på bachelor-niveau, heraf en del på begynderniveau. Det skal derfor også medtænkes, at mange af deltagerne har haft begrænset faglig og studieteknisk rutine, da de deltog i podcasting-forsøgene.

Endelig skal nævnes som et kuriosum, at ingen af de udvalgte publikationer forholder sig eksplicit til, at podcasting måske nok er et nyt begreb, men at lydoptagelser og levende billeder har været anvendt på forskellig vis i undervisning gennem de seneste hundrede år (Reiser, 2001). Den ældre litteratur om audiovisuelle undervisningsmidler synes gennemgående at være kørt i depot.

\section{Effektmålinger af undervisningspodcasts}

Den læringsmæssige effekt af undervisningspodcasts ses målt på tre forskellige måder ved hjælp af:

- Spørgeskemaer, fokusgrupper samt individuelle interviews på baggrund af et undervisningsforløb,

- Måling af tilgang til materialerne, samt måling af de studerendes præstationer på baggrund af et undervisningsforløb,

- Kontrollerede forsøg på baggrund af en konstrueret brugssituation.

Der forekommer visse overlap mellem de to første kategorier, ligesom forsøgene i den tredje kategori naturligvis kan inkludere såvel spørgeskemaer som interviews. Men i det store og hele er der tale om tre forskellige tilgange, der fokuserer på henholdsvis oplevelse, præstation og kognition. I det følgende diskuteres først undersøgelser af oplevelser og dernæst af præstation. De ganske få artikler om kontrollerede forsøg inddrages i forbindelse med diskussionen af de to første kategorier. Endelig ligger der i materialet en ikke altid ekspliciteret effekt på undervisernes forståelse af deres egen praksis. Den berøres også kort i det følgende. 


\section{Oplevelse af podcasts}

Podcasting er af mange blevet modtaget med enthusiasme over de talrige nye og spændende muligheder, teknologien åbner for. Der er gjort en del antagelser om de sandsynlige fordele ved at anvende podcasts, og der er gennemført undersøgelser af undervisernes og de studerendes forventninger til teknologien (Bull et al., 2007; Gribbins, 2007). Det er grund til at være særligt opmærksom på disse forventninger, uanset om de er mere eller mindre velfunderede, fordi de ofte har dannet udgangspunkt for udformningen af de spørgeskemaer og spørgeguides, som er anvendt ved undersøgelser af effekten af podcast-støttet undervisning. I den aktuelle litteraturgennemgang er det ikke er lykkedes at identificere væsentlige kvaliteter ved podcasting, der kan supplere eller modsige de allerede kendte forventninger. Derfor giver det mening at strukturere præsentationen i det følgende ud fra de "almindelige" forventninger, som går igen i en stor del af podcast-litteraturen. Udgangspunktet er således Jowitt (2008), som leverer en nøgtern og fyldig oversigt i ti punkter over de vigtigste forventninger til podcasting:

1. Mobilitet, fleksibilitet og bekvemmelighed,

2. Mulighed for at afspille, hvor og hvornår man vil,

3. Mulighed for at multitaske, mens man bevæger sig,

4. Let internetadgang, når der er brug for det,

5. Mulighed for at lytte igen og igen,

6. Mulighed for at bestemme afspilningshastighed,

7. Automatisk subskription ved hjælp af RSS,

8. Frit, individuelt valg af, hvad man vil høre,

9. Godt for de auditivt begavede,

10. Forbedret service for fjernundervisnings- og online-studerende.

Punkterne 2 og 3 og til dels 1 bygger på forventninger om, at mobile afpilningsenheder bruges på en ensartet måde, uanset hvad der afspilles. Bell et al. (2007) lægger ligefrem ud med en statistik for generel anvendelse af mobile afspillere, der bl.a. viser, at en tredjedel af brugerne spadserer eller bliver transporteret, mens de lytter. De samme forfattere når derefter frem til, at man ikke genfinder et lignende mønster, når det gælder studerendes brug af undervisningspodcasts. Dette bekræftes af, at der er betydelig overvægt af pc-brug i det store flertal af de øvrige undersøgelser, hvor der redegøres for brugssituationen. En del af disse er dog af relativt ældre dato (Barker, 2007; Maag, 2006; Malan, 2007; Muppala \& Kong, 2007). Hos Evans (2008), som videregiver erfaringer fra en storby, er tendensen mindre klar, mens Saeed \& Yang (2008) påviser udstrakt brug af mobile afspillere. Erfaringerne fra Duke University skiller sig ud, for her er undervisningen lagt an på, at de studerende har rådighed over en mobil afspiller. Men selv på denne læreanstalt er der studerende, 
som foretrækker pc'en til afspilning (Belanger, 2007b). Ogawa \& Nickles (2006) beretter om studerende, der lytter til forelæsninger, mens de kører bil, går rundt på campus eller laver mad, men det er ikke klart, om der er tale om undtagelser, som det ellers er tilfældet i fleste andre undersøgelser, hvor ukonventionelle brugssituationer fremhæves.

Der kan være både praktiske og studieadfærdsmæssige grunde til, at flertallet af de studerende tilsyneladende fravælger mobilafspilning. Hvad det praktiske angår, skal det bemærkes, at anvendelsen af mobile afspillere ikke er slet så universel, som man måske kunne tro, når man færdes i det offentlige rum. Det gælder specielt for de tidlige undersøgelser, at en del studerende dengang ikke ejede en egnet mobil afspiller. De studerende har hentet lydfilerne ned på deres pc, og ikke nødvendigvis ved hjælp af RSS (punkt 7). I mange af undersøgelserne er filerne blevet anbragt i det lokale Learning Management System (LMS) eller på en særlig webside, og det har derfor krævet en ekstra indsats, hvis brugerne ville have dem anbragt i den rigtige mappe, så filerne let kunne overføres til en afspiller (endnu en arbejdsgang). Med introduktionen i efteråret 2007 af mobile afspillere, som direkte kan tilsluttes internettet trådløst, er det blevet langt lettere at downloade lyd- og videomaterialer, og det kan endda lade sig gøre, mens man er på farten, blot der er trådløst internet til rådighed.

Hvad angår studieadfærd, er det en gennemgående konstatering $\mathrm{i}$ undersøgelserne, at de studerende gerne benytter lydfiler, når de sidder roligt, omgivet af lærebøger og forelæsningsnoter. På den måde bliver podcastene et materiale, som naturligt indgår som supplement til de øvrige studiematerialer. Hürst et al. (2007) gennemførte en spørgeskemaundersøgelse blandt eksterne (dvs. ikke-indskrevne) brugere af deres undervisningspodcasts. Også her er pc-anvendelsen markant større end den mobile brug. Men denne sidste er dog af en størrelsesorden, der kan give anledning til at overveje, om den offentlighed, som vælger at lytte til universiteternes podcasts, måske betragter forelæsningerne som en art seriøse radioprogrammer snarere end som undervisningsmaterialer.

Muligheden for at gennemlytte en præsentation flere gange (punkt 5) er måske den kvalitet ved podcasts, som har den mest indlysende effekt. En enkelt undersøgelse, som omtales mere udførligt senere, kan ligefrem sætte tal på den positive virkning (McKinney et al., 2008). Flere andre studier bekræfter, at de studerende med udbytte bruger podcasts til eksamensforberedelse og til repetition (Bongey et al., 2006; Clark et al., 2007; Edirisingha et al., 2007a; Frydenberg, 2006; Faser et al., 2008; Guertin et al., 2007; Lane, 2006; Lazzari, 2009; Maag, 2006; McKinney \& Page, 2009; Ogawa \& Nickles, 2006). Med podcasts kan man terpe pensum generelt, finde tilbage til vanskelige punkter, og omvendt kan man springe de ting over, som man allerede er godt inde i (punkt 8). Man kan teste sig 
selv, og man kan sammenholde forelæsningen med lærebøger og noter. Specielt hvad det sidste angår, gør Evans (2008) den interessante observation, at de studerende opfatter podcasts som mere effektive end deres egne noter, når de skal indlære et stof.

Uafhængigheden af tid og sted og den bekvemme adgang til materialerne (punkterne 1, 2, 4 og 10) betragtes generelt som et af de store goder ved podcasting (bl.a. Jowitt, 2008; Edirisingha et al., 2007a). Der konstateres klare fordele ved, at den studerende ikke går glip af en forelæsning, hvis han er forhindret $\mathrm{i}$ at møde op, at den studerende bedre kan tilrettelægge sin tid, når der ikke er faste mødetider, samt at den studerende kan høre forelæsningen på et tidspunkt, hvor han er veloplagt og har adgang til supplerende materialer, som kan konsulteres undervejs.

Potentialet for fjernundervisning ved hjælp af podcasting er naturligvis stort. Men i den sammenhæng gælder det om at skelne mellem den lette adgang til selvstudier og uformel læring, som blandt andet iTunes University tilbyder, og så den programlagte, superviserede og kontrollerede undervisning, som deltagerne i et autoriseret fjernundervisningsforløb modtager. Det er den sidste, som er emnet her.

En af de mest udbredte fordomme om podcasting er, at de studerende vil droppe tilstedeværelsesundervisningen, når de kan hente kursernes indhold på nettet. En række undersøgelser beskæftiger sig med dette forhold, og den generelle vurdering er, at frafaldet under forsøgene med podcasting ikke har været et væsentligt problem (fx Bongey et al., 2006). Spørgsmålet er også, om det er et meningsfuldt problem, hvis man betragter undervisning som andet og mere end udenadslære. McKinney \& Page (2009) konkluderer således, at undervisningsteknologi i sig selv ikke er en garanti for, at der finder læring sted, og at nogle studerende går tabt, når man erstatter tilstedeværelsesundervisning med podcasts.

Mulighed for at bestemme afspilningshastighed (punkt 6) er særlig relevant i forbindelse med sprogundervisning, hvor også muligheden for gentagelse, og for i det hele taget at få adgang til et stort og varieret lyd- og videomateriale tydeligvis opleves som noget, der styrker undervisning og dygtiggørelse (Earp et al., 2006; Faser et al., 2008; O’Bryan \& Hegelheimer, 2007).

Argumentet, at podcasting er særligt til fordel for de auditivt begavede (punkt 9), har rødder i diskussionerne fra begyndelsen af 1990'erne om anvendelse af multimedier i undervisningen, og den kan teoretisk funderes i Gardners (1983) tanker om læringsstile. Skønt læringsstile nævnes kort af flere forfattere, kommer kun få nærmere ind på dem som en mulig forklaring på effekten af podcasts (Bull et al., 2007; Muppala \& Kong, 2007). 
Potentialet for at styrke læring gennem anvendelse af en kombination af medier omtales som en drivkraft i Duke Universitys store iPod-initiativ (Belanger, 2007a; 2007b), men er ellers ikke et fremherskende tema i det undersøgte materiale.

Endelig skal nævnes, at mange undersøgelser har forsøgt at fastslå de studerendes generelle tilfredshed med podcasts i undervisningen. Selv om der er enkelte eksempler på, at de studerende er afvisende over for podcasts (Bell et al., 2007; Edirisingha et al., 2007a), synes der at være nærmest overvældende positive reaktioner på den nye teknologi. Som nogle få eksempler kan nævnes, at Clark et al. (2007) blandt 30 studerende fandt, at $96 \%$ mente, at podcasting støttede og forbedrede deres læring; at $89 \%$ mente at det gjorde dem mere aktive; samt at alle gerne ville have flere podcasts i undervisningen. At $71 \%$ af Jowitts (2008) 86 studerende havde en positiv holdning; eller at $79 \%$ af Maags (2006) i alt 110 studerende mente at podcasts havde været en hjælp, og at $81 \%$ gerne ville have flere podcasts i fremtiden. Andre tal er mindre ekstreme, men ingen af undersøgelserne kan opvise et flertal imod podcasting.

De mange positive udsagn må stå til troende som vidnesbyrd om, at podcasting kan være til gavn for det generelle studiemiljø. Dog skal det bemærkes, dels at en del af resultaterne er fremkommet gennem svar på en Likert-skala på spørgsmål, som det kan være svært at være uenig i, hvis den studerende i øvrigt har været positiv over for undervisningen, dels at svarprocenterne i en del undersøgelser er så lave, at resultaterne ikke kan anses som troværdige. Det kan heller ikke helt afvises, at selve det, at der optræder nye elementer i undervisningen har været ansporende - altså en form for Hawthorne-effekt. Men, som beskrevet i det foregående, er der en række enkeltforhold, som vurderes så positivt af de studerende, at den overordnede tilfredshed giver god mening.

\section{Præestationer forbundet med podcasts}

Litteraturgennemgangen har ført frem til et meget beskedent antal målinger af studerendes præstationer i forbindelse med anvendelse af podcasts. Disse undersøgelser er på ingen måde sammenlignelige, og ud over de forhold, som nævnes i den følgende oversigt, er der en række ydre faktorer (bl.a. studiemiljø, fag, undervisningsform, undervisningstradition, teknologianvendelse, anvendelsessituation, intensitet af anvendelse), som eventuelt bør tages i betragtning. Erfaringerne med studerendes præstationer er kort resumeret i det følgende, som fremhæver hovedtræk i undersøgelserne, men ikke forsøger at vurdere kvaliteten af dem:

Abt \& Barry (2007) inddelte på grundlag af en skriftlig prøve 50 studerende i legemsøvelser i en podcast-gruppe og en kontrolgruppe. Podcast-gruppen fik seks podcasts til rådighed i en periode over seks uger. 
Kontrolgruppen fik udskrifter af podcast'ene stillet til rådighed. Ved en ny prøve efter seks uger, viste podcast-gruppen en fremgang på $46 \%$ og kontrolgruppen en fremgang på $43 \%$. Forfatterne konkluderer, at podcasts ikke er skadelige, og at der er en $48 \%$ sandsynlighed for, at podcasts har haft en gavnlig effekt, men at fordelene ved at benytte podcasts frem for tekst er uhyre beskedne.

Baker et al. (2008) gennemførte et forsøg over ét semester, hvor to 10minutters podcast blev benyttet som supplement $i$ et kursus i flyvning (aviation) med 48 konfrontationstimer. De to podcasts var tilgængelige i hele semesteret, men der er ikke vidnesbyrd om, at podcast'ene blev inddraget aktivt i undervisningen. Der blev afholdt prøver (quiz) i de emner, podcast'ene dækkede, og resultaterne af disse viser, sammenlignet med resultater fra lignende prøver i et tidligere semester, at der statistisk set ikke kan påvises en effekt af at supplere undervisningen med podcasts. Det skal bemærkes, at datamaterialet er spinkelt (fire besvarelser fra podcast-holdet og 17 fra det tidligere kursus).

Carle et al. (2009) foretog et sammenlignende studie af to hold psykologistuderende (i alt 25) på bachelor-niveau, hvor det ene hold blev undervist konventionelt, mens undervisningen på det andet hold blev støttet dels med podcast-optagelser af forelæsningerne, dels med underviser-feedback på lydoptagelser af samtlige gruppediskussioner. Podcast-holdet scorede væsentligt højere i bedømmelsen af skriftlige opgaver end kontrolgruppen, og de studerende markerede i en spørgeskemaundersøgelse, at de havde haft større studieaktivitet end normalt. I analysen af resultaterne lægger forfatterne vægt på, at feedback på de studerendes gruppediskussioner, hvor underviseren (efterfølgende inden for få dage) var "til stede" i alle grupper, gav rettidig vejledning, begrænsede den "social loafing", som kan optræde i rent studenterstyrede grupper, samt motiverede til mere aktiv deltagelse i diskussionerne.

Hodges et al. (2008) undersøgte i et forsøg med 17 kvindelige kommunikationsstuderende på B.A.-niveau fire faktorer, der erfaringsmæssigt har indflydelse på akademisk performance: teknologisk selvhjulpenhed (efficacy), akademisk selvhjulpenhed, akademisk selvtilrettelæggelse (regulation) og kognitiv stil (her forstået som evne til at udskille væsentlig information). Forsøget omfattede fem korte, supplerende forelæsninger og en afsluttende test. Kun kognitiv stil synes at have betydning, men forfatterne tager store forbehold for valg af metode og omfang af empiri i deres vurdering af resultaterne.

Kurtz et al. (2007) udskiftede i et datalogikursus de konventionelle forelæsninger med podcasts (bestående af forelæsning og dialog med studerende) og anvendte i stedet konfrontationstimerne til opgaveløsning 
og arbejde på kursusprojektet. Karakteren for kurset blev beregnet ud fra en eksamen (40\%), projekt ( $40 \%$ ) og aktiv deltagelse (20\%).

Sammenlignet med semesteret før omlægningen af undervisningen scorede projekterne 9,5\% højere, eksamensgennemsnittet lå mindre end $1 \%$ højere, og der blev givet flere høje karakterer og færre mellemkarakterer i den samlede bedømmelse af de studerendes præstation. Af evalueringen af kurset fremgår, at de studerende oplevede en større arbejdsbyrde end ved konventionel undervisning.

Lakhal et al. (2007) gennemførte en spørgeskemaundersøgelse hvor 192 (ud af 308) informatikstuderende på B.A.-niveau besvarede et spørgeskema. Særligt for kurset var, at det blev tilbudt både som tilstedeværelses- og fjernundervisning (både tidstro og podcastede optagelser af forelæsninger). Konklusionen var, at de 42 studerende, som benyttede sig af podcasts, gav udtryk for, at de oplevede større studieeffektivitet og tilfredshed. En række andre faktorer gav ikke statistisk signifikante resultater. Forfatterne påpeger selv, at at fjernundervisningsformatet har positiv indflydelse på resultaterne, samt at en strejke blandt underviserne fik færre studerende til at gå til eksamen, og at disse opnåede relativt høje karakterer. Det overvejes ikke, om de 42 podcastlyttere også på andre måder udmærker sig som særligt engagerede studerende.

Lazzari (2009) rapporterer om en kompleks undervisningssituation med både fuldtids- og deltidsstuderende (heraf var nogle udelukkende involveret gennem fjernundervisning). Alle deltagerne i et kursus i multimediekommunikation havde adgang til en serie podcasts af 5 - 15 minutters varighed med resuméer af forelæsninger eller uddybninger af særlige emner. De fuldtidsstuderende gennemførte desuden tre øvelser med selv at producere podcasts. Sammenlignet med de to foregående år var eksamensgennemsnittet efter introduktion af podcasts lidt højere, idet det var nærmest uændret for de deltidsstuderende og klart højere for de fuldtidsstuderende. Hvad de deltidsstuderende angår, forklarer Lazarri den manglende effekt med ukendskab til materialet (tal for tilgang til hele kursus-webstedet angives, men ikke tal for de enkelte podcasts). De fuldtidsstuderendes bedre resultater begrundes med, at deres aktive engagement i produktion af podcasts fremmede samarbejde, refleksion og fordybelse i stoffet. I denne antagelse ligger implicit, at de studerende meget vel kan have trukket på podcast-undervisningsmaterialerne. Men dette forhold uddybes ikke. Det skal bemærkes, at den aktivt inddragende undervisningsform var ny i forhold til de tidligere år, der sammenlignes med, samt at holdstørrelsen var mindre.

McCombs \& Liu (2007) sammenlignede karaktererne fra to semestres undervisning i samme kursus med samme underviser, men henholdsvis med og uden podcasting (nærmere detaljer mangler). På holdet med 
podcasting blev der givet $12 \%$ flere topkarakterer, og også karaktergennemsnittet lå højere. I en generel spørgeskemaundersøgelse svarede godt en tredjedel af de studerende $(\mathrm{N}=632)$ positivt på, at de oplevede at podcasting hjalp dem til et bedre resultat.

McKinney et al. (2008) gennemførte et forsøg med to grupper af psykologistuderende, hvor den ene gruppe hørte en 25 minutters forelæsning i klassen, og den anden gruppe fik udleveret en optagelse af præcis den samme forelæsning. Begge grupper fik udleveret en udskrift af den PowerPoint-præsentation, der blev benyttet i forelæsningen. En uge senere deltog begge grupper i en multiple-choice prøve (34 podcast-lyttere og 32 forelæsningsdeltagere). Den gennemsnitlige score for podcastgruppen var 71,24 \% mod forelæsningsgruppens $62,47 \%$. Forfatterne undersøgte yderlige, om de studerende havde taget noter fra forelæsningen og kunne konstatere, at notetagerne scorede væsentligt højere end dem, som blot passivt havde lyttet. Det er væsentligt at bemærke, at 22 af de 34 studerende havde lyttet mere end én gang til forelæsningen. En enkelt undlod at lytte, og alt i alt blev forelæsningen afspillet 75 gange.

Ormond (2008) lod ét af fire hold på et datalogikursus benytte podcasts. Dette hold opnåede 4,75 \% højere score ved eksamen end gennemsnittet af tre andre hold. Forfatteren søger ikke at forklare dette forhold, og han gør heller ikke rede for, hvad podcast'ene bestod i, og hvordan de blev inddraget i undervisningen.

Smith \& Fidge (2008) redegør for et forsøg med at lægge undervisningen i datalogi om fra rene forelæsninger til interaktive demonstrationer, hvor grundbegreberne blev forudsat tilegnet gennem aflytning af i alt 20 korte podcasts (af 5 - 25 minutters varighed). Sammenlignet med niveauet for det tilsvarende kursus året før blev der givet flere høje karakterer. Til gengæld bestod $7 \%$ færre studerende kurset (ud af ca. 300 studerende pr. årgang). En analyse af tilgangen til podcast-ressourcerne viser, at nogle studerende aldrig benyttede dem. Dette, sammen med et ændret rekrutteringsgrundlag og en større omlægning af pensum, kan bidrage til at forklare den ringere gennemførselsprocent. Forfatterne sandsynliggør, at de noget højere karakterer, som nogle af de studerende opnåede, kan være et resultat af studieadfærd, snarere end en effekt af podcasts som sådan, i og med at stærke studerende typisk sætter sig ind i alt det materiale, der tilbydes i forbindelse med undervisningen.

\section{Underviserne og podcast}

En del af podcastforsøgene indskrænker sig til at dokumentere den afholdte undervisning i fuld udstrækning eller gennem optagelse af udvalgte forelæsninger eller gennem mere eller mindre fyldige resuméer af forelæsninger. Men der findes adskillige eksempler på mere 
ukonventionelle anvendelser, som har givet underviserne anledning til at eksperimentere med og reflektere over deres undervisningspraksis.

I nogle tilfælde er podcasts på forskellig vis anvendt som supplement til undervisningen. Bell et al. (2007) benyttede således (med begrænset gennemslagskraft) podcasts som en form for nyhedstjeneste knyttet til kurset. Hvert podcast (15 - 60 minutter) opsummerede foregående uges pensum, introducerede emner, som ville blive taget op senere i forløbet, påmindede om tidsfrister, diskuterede aktuelle emner med tilknytning til undervisningen (i datalogi) og udskrev en konkurrence, som de studerende kunne besvare pr. e-mail. Mathiasen \& Schrum (2008) supplerede undervisningen med 5 - 7 minutters videoer, hvoraf nogle demonstrerede praksissituationer, mens andre gennemgik et udvalgt emne.

Flere har forsøgt at bryde forelæsningernes énvejskommunikation ved at indlægge en eller anden form for dialog med de studerende i de podcasts, som supplerede undervisningen. Nathan \& Chan (2007) udviklede således en række podcasts, hvor formodet vanskelige emner inden for forretningsstrategi blev uddybet i en diskussion mellem underviseren og en studerende. Abt \& Barry (2007) valgte et format med spørgsmål-og-svar til seks små montager, hvis indhold supplerede fysiologi-forelæsningerne. Edirisingha et al. (2007a) kombinerede gentagelse af vigtige pointer med interviews med studerende og samtaler om opgaveløsning de studerende imellem i seks podcasts i et kursus i interkulturel kommunikation.

Carle et al. (2009) brød med deres forsøg grænserne for, hvor mange steder en underviser kan opholde sig på én gang. Ved at lydoptage samtlige gruppediskussioner på kurset og efterfølgende at kommentere dem, kombinerede de gruppediskussion med aktiv lærerstyring, motiverede de studerende til at deltage konstruktivt i diskussionerne og kom (i princippet) i dialog med hver enkelt studerende på holdet.

En aktiv inddragelse af de studerende er i nogle tilfælde foregået ved at lade de studerende selv fremstille podcasts. Det kan være i form af bearbejdelse af stoffet, som hos Frydenberg (2006), der lod grupper af to studerende producere og dele med resten af holdet ugentlige 6 - 10 minutters video-podcasts om emner, som blev gennemgået $i$ forelæsningerne om teknologi. Lazzari (2009) lod de studerende arbejde i grupper med tre øvelser, der indebar henholdsvis en bearbejdning af gennemgået pensum og præsentation af nyt stof. Et forskerhold har eksperimenteret med at lade ældre studerende producere faglige podcasts til nye studerende (Chan et al., 2006; Lee et al., 2008b). Fra Duke University, som er en podcasting pionérinstitution, er der adskillige eksempler på, at de studerende er blevet inddraget som medproducenter af 
viden, fx i forbindelse med at indspille en kortfilm på fransk som led i sprogundervisningen (Earp et al., 2006).

Sprogundervisning er i det hele taget et område, hvor podcasting synes at gøre en positiv forskel i forbindelse med lytteøvelser, hvor udvalget af eksempler med internettet er blevet langt større, bredere og mere hverdagsagtigt end tidligere, samt i forbindelse med udtaleøvelser, som den studerende selv kan gennemføre, eventuelt under supervision fra en sproglærer. Særlig betydning har podcasting for studerende, der ikke har undervisningssproget som modersmål, og som har brug for sprogtræning (O'Bryan \& Hegelheimer, 2007) eller blot for at kunne arbejde grundigt med forståelsen af forelæsningerne (Clark et al., 2007; Muppala \& Kong, 2007).

Endelig kan podcasts benyttes som erstatning for undervisning. På det beskedne plan er der eksempler på, at mundtlig evaluering af studerendes præstationer kan erstattes med podcasts, så de studerende har mulighed for at genhøre den (France \& Wheeler, 2007; Maag, 2006). Ribchester et al. (2008) pointerer dog, at teknologien i selv ikke en garanti for, at der opnås læringsudbytte af bedømmelsen.

Mere radikalt kan man erstatte den traditionelle forelæsning med et podcast og bruge konfrontationstimerne til noget andet. Det kan dreje sig om enkelte timer ud af et længere forløb, hvor visuel præsentation spiller en væsentlig rolle (McKinney \& Page, 2009). Det kan have form af kompakte præsentationer af grundlæggende facts, teorier og metoder, der forudsættes kendt, inden timerne i klasseværelset, hvor der så bliver mere tid til diskussion og eksemplifikation (Smith \& Fidge, 2008) eller på øvelser (Kurtz et al., 2007). Der kan være tale om en systematisk realisering af en "inverted classroom model" (det spejlvendte klasseværelse), hvor al pensum-gennemgang har form af podcasts (Gannod et al., 2008). Eller det kan handle om ren stordrift, hvor podcasts erstatter dublering af forelæsninger, når der er mange hold inden for samme fag (Ogawa \& Nickles, 2006).

\section{Opsummering}

I det foregående er præsenteret tre forskellige former for indvirkning på universitetsundervisning ved indførelse af podcasting. Samlet tegner der sig et forholdsvis kompliceret og langt fra entydigt billede.

Det står klart, at det ikke uden videre lader sig gøre kvantitativt at måle en effekt af podcast-lytning i de studerendes eksamenspræstationer. Den resultatfremgang, som nogle undersøgelser kan påvise, skal ikke nødvendigvis tilskrives teknologien som sådan. Snarere er der tale om et samspil mellem teknologi og undervisningsformat eller mellem teknologi 
og studieadfærd. Hvad det første angår, er det næppe overraskende, at der kan være en positiv effekt ved øget aktivering af de studerende gennem supplering eller ændring af det konventionelle forelæsningsformat. Hvad studieadfærd angår, spiller muligheden for at genhøre et stof adskillige gange en afgørende rolle for at forstå de slående resultater, McKinney et al. (2008) kommer frem til. I gentagelsesmuligheden, gerne kombineret med andre materialer, er der klare fordele, når der er tale om at tilegne sig et stof, hvilket også tydeligt fremgår både af de studerendes egne oplevelser af podcasts og i de forsøg, hvor hovedparten af de studerende ikke har undervisningssproget som modersmål. Omvendt dokumenterer et par af undersøgelserne, at der opstår et reelt problem, hvis de studerende ikke opsøger det undervisningsmateriale, som overføres til podcasts.

Som nævnt findes der på nuværende tidspunkt kun et fătal af undersøgelser af podcasts i undervisningen foretaget over længere tid, og de mere generelle undersøgelser af de studerendes respons til podcasting har en tendens til at være lidt vage. Ikke desto mindre tyder meget på, at de studerende (heraf mange på begynderniveau), som primært færdes i en undervisningskultur domineret af forelæsninger, har taget godt imod podcasting og bruger teknologien hensigtsmæssigt som et supplement i studierne. Skønt det ikke lader sig dokumentere, er det nærliggende at antage (og værd at følge over længere tid), at større effektivitet i og ikke mindst motiverende tilfredshed med undervisningstilbud og services på sigt meget vel kan have en positiv virkning på det samlede studieforløb i form af kortere studietid, højere gennemførselsprocent, og måske også et forbedret akademisk niveau.

Hvad det akademiske niveau angår, kan det have betydning, at podcasting faktisk synes at rokke ved den konventionelle forelæsningsform. Podcasts kan afhjælpe kendte problemer med at opfatte det stof, der meddeles. Men, vigtigere, er der tegn på, at systematisk anvendelse af podcasts kan nedbringe den tid, der bruges på at docere og dermed skabe plads for diskussion og øvelser og højere grad af refleksion. I dette ligger der også en læreproces og refleksion over egen praksis for underviserne: Dette kan måske vise sig at være en af de mere interessante læringsmæssige effekter af udbredelsen af podcasting-teknologien.

Gang på gang er ny teknologi blevet udråbt som middel til at forny og forbedre undervisningen - tænk blot på sproglaboratoriet, computeren, multimedier, internettet, og på det seneste Web 2.0 og podcasting. Ud fra præsentationen af de mange undersøgelser i det foregående kan det nok engang slås fast, at det ikke er teknologien som sådan, men derimod anvendelsen af den, som kan gøre en forskel. For podcasting - i forbindelse med undervisning - gælder det særlige, at det er svært at påpege radikale nyskabelser i den grundlæggende funktionalitet. Lyd og levende billeder 
har som nævnt været benyttet i undervisningen gennem hundrede år. Det egentlige nye er den frie, ubegrænsede, billige og lette adgang til at kopiere, afspille og producere audio- og videofiler. Det har skabt nye forbrugsvaner og brugssituationer, og det er dem, der har indflydelse på undervisningens form og måske også på læringsudbyttet.

Ikke mindst i Danmark, hvor samtalen betragtes som grundlæggende for god undervisning, og hvor reflekteret forståelse rangerer højere end udenadslære, er podcasting blevet mødt med nogen skepsis. Det er derfor heller ikke overraskende, at den eneste undersøgelse, hvor de studerende vurderer podcast-forelæsninger som totalt spild af tid, er dansk (Mathiasen \& Schrum, 2008). Men som det er forsøgt godtgjort på de foregående sider, er podcasting ikke nødvendigvis blot et middel til at fastholde en dybest set forældet undervisningsform. Podcasting kan anvendes på mange forskellige måder, og teknologien kan sagtens benyttes til at inddrage de studerende som medproducenter af viden. Dertil kommer, at podcasting ser ud til at kunne opfylde nogle af de studerendes behov for at have et "sikkerhedsnet" i forbindelse med fravær og en støtte i forbindelse med repetition og forståelse af komplekse forklaringer.

Introduktion af podcasting som en del af universitetsundervisningen kan begrundes forskelligt som bidrag til folkeoplysning, dokumentation, livslang læring, markedsføring af universiteterne, netbaseret læring, videndeling, samt naturligvis forbedring af uddannelsernes kvalitet. Hver af disse kan have en værdi, som retfærdiggør investeringen i podcasting. Hvad angår akademisk niveau, som er emnet for denne artikel, synes der at kunne påvises en effekt. Men det er usikkert, hvor stor den er (ikke mindst $\mathrm{i}$ en typisk dansk undervisningssammenhæng) og dermed også, om det giver mening at afsætte ressourcer til podcasting i stor målestok. Der er derfor behov for studier over tid med systematiske podcast-forsøg, som kan vise hvor meget, hvordan, og med hvilken effekt de studerende benytter podcasting-tilbuddene.

\section{Litteratur}

Abt, G. \& Barry, T. (2007). The Quantitative Effect of Students Using Podcasts in a First Year Undergraduate Exercise Physiology Module. Bioscience Education e-Journal, 10.

Baker, R., Harrison, J., Thornton, B. \& Yates, R. (2008). An Analysis Of The Effectiveness Of Podcasting As A Supplemental Instructional Tool: A Pilot Study. College Teaching Methods \& Styles Journal, 4(3), 49 - 54.

Barker, T. (2007). Podcasting in an Advanced Computer Science. In D. Remenyi (Ed.), Proceedings of the 6th Conference on E-learning: ECEL 2007 (pp. 25-31). Nr Reading: Academic Conferences Limited. 
Belanger, Y. (2005). Duke University iPod First Year Experience Final Evaluation Report. Durham NC: Duke University.

Belanger, Y. (2007a). Summary of DDI Instructional Programs, 2006-2007. Durham NC: Duke University.

Belanger, Y. (2007b). CIT Report on Fall 2006 Duke Digital Initiative Instructional programs. Durham NC: Duke University.

Bell, T., Cockburn, A., Wingkvist, A. \& Green, R. (2007). Podcasts as a supplement in tertiary education: an experiment with two Computer Science courses. In D. Parsons \& H. Ryu (Eds.), Mobile Learning Technologies and Applications (MoLTA) 200. Auckland: Massey University.

Blædel, D. (2007, 30 April). Forelæsningerne ud af auditoriet. Information.

Bongey, S. B., Cizadlo, G. \& Kalnbach, L. (2006). Explorations in coursecasting: podcasts in higher education. Campus-Wide Information Systems, 23(5), 350 - 367.

Bull, P. H., Tyler, D. \& Eaton, D. (2007). A neo-constructivist teaching tool: Perceptions of HBCU faculty to podcasting as a teaching and learning tool. In C. Crawford et al. (Ed.), Proceedings of Society for Information Technology and Teacher Education International Conference 2007 (pp. 1404-1409). Chesapeake, VA.: AACE.

Campbel, G. (2005, November/December). There's Something in the Air: Podcasting in Education. EDUCAUSE Review Magazine, 40, 32 - 46.

Carle, A. C., Jaffee, D. \& Miller, D. (2009). Engaging college science students and changing academic achievement with technology: A quasiexperimental preliminary investigation. Computers \& Education, 52(2), 376-380.

Chan, A., Lee, M. J. W. \& McLoughlin, C. (2006). Everyone's learning with podcasting: A Charles Sturt University experience. In L. Markauskaite, P. Goodyear \& P. Reimann (Eds.), Proceedings of the 23rd annual ascilite conference: Who's learning? Whose technology? (pp. 111 - 120). Sydney: University of Sydney.

Clark, S., Taylor, L. \& Westcott, M. (2007). Using short podcasts to reinforce lectures. In Proceedings of the Assessment in Science Teaching and Learning Symposium (pp. 22 - 27). Sydney: UniServe Science.

Clark, S., Sutton-Brady, C., Scott, K. M. \& Taylor, L. (2007). Short podcasts: The impact on learning and teaching. In A. Austin \& J. Pearce (Eds.), Proceedings of mLearn Conference 2007 (pp. 285-289). Melbourne: University of Melbourne.

Cochrane, T. (2005). Podcasting the do-it-yourself guide. Indianapolis: Wiley. 
Doolittle, P. E., Tusk, D. L., Byrd, C. N. \& Mariano, G. J. (2008). iPods as Mobile Multimedia Learning Environments: Individual Differences and Instructional Design. In H. Ryu \& D. Parsons (Eds.), Innovative Mobile Learning (pp. 83 - 101): Idea Group.

Earp, S., Belanger, Y. \& O’Brien, L. (2006). Duke Digital Initiative End of Year Report. Durham NC: Duke University.

Edirisingha, P. (2007). The "double life" of an i-Pod: A case study of the educational potential of new technologies. Paper presented at the Online Educa 2006, Berlin.

Edirisingha, P., Rizzi, C., Nie, M. \& Rothwell, L. (2007a). Podcasting to provide teaching and learning support for an undergraduate module on English Language and Communication. Turkish Online Journal of Distance Education, 8(3), 87-107.

Edirisingha, P., Salmon, G. K. \& Fothergill, J. C. (2007). Profcasting: a pilot study and guidelines for integrating podcasts in a blended learning environment. In prepublication draft. Leicester: Leicester Research Archive.

Evans, C. (2008). The effectiveness of m-learning in the form of podcast revision lectures in higher education. Computers \& Education, 50(2), 491 $-498$.

Faser, B. R., Abdous, M. h. \& Camarena, M. M. (2008). The Impact of Podcasting on Students' Learning Outcomes. In R. d. C. V. Marriott \& P. L. Torres (Eds.), Handbook of Research on E-Learning Methodologies for Language Acquisition (pp. 339 - 350): Information Science Reference.

France, D. \& Wheeler, A. (2007). Reflections on using podcasting for student feedback. Planet, 18, 9 - 11.

Frydenberg, M. (2006). Principles and pedagogy: The two P's of podcasting in the information technology classroom. In The Proceedings of ISECON 2006, v 23 (Vol. §3354). Dallas.

Gannod, G. C., Burge, J. E. \& Helmick, M. T. (2008). Using the inverted classroom to teach software engineering. In Proceedings of the 30th international conference on Software engineering (pp. 777-786 ). Leipzig, Germany ACM.

Gardner, H. (1983). Frames of mind : the theory of multiple intelligences. New York: Basic Books.

Gribbins, M. (2007). The perceived usefulness of podcasting in higher education: A survey of students' attitudes \& intention to use. Paper presented at the Proceedings of the Second Midwest United States Association for Information Systems, Springfield, IL. 
Guertin, L. A., Bodek, M. J., Zappe, S. E. \& Kim, H. (2007). Questioning the Student Use of and Desire for Lecture Podcasts. MERLOT Journal of Online Learning and Teaching, 3(2), 133 - 141.

Hew, K. F. (2008). Use of audio podcast in K-12 and higher education: a review of research topics and methodologies. Educational Technology Research and Development, OnlineFirst.

Hodges, C. B., Stackpole-Hodges, C. L. \& Cox, K. M. (2008). Self-Efficacy, SelfRegulation, and Cognitive Style as Predictors of Achievement with Podcast Instruction. Journal of Educational Computing Research, 38(2), 139 - 153.

Hürst, W., Welte, M. \& Jung, S. (2007). An evaluation of the mobile usage of e-lecture podcasts. In Proceedings of the 4th international conference on mobile technology, applications, and systems and the 1st international symposium on Computer human interaction in mobile technology (pp. 1623). Singapore: ACM.

IMPALA. (2007). INFORMAL MOBILE PODCASTING AND LEARNING ADAPTATION. Retrieved January 27, 2009, from http://www2.le.ac.uk/projects/impala.

Janossy, J. (2007). Student Reaction to Podcast Learning Materials: Preliminary Results. In 12th annual Instructional Technology Conference: "Engaging the Learner" (pp. 98 - 120). Murfreesboro: Middle Tennessee State University.

Jowitt, A. (2008). Perceptions and usage of library instructional podcasts by staff and students at New Zealand's Universal College of Learning (UCOL). Reference Services Review, 36(3), 312 - 336.

Kurtz, B. L., Fenwick, J. B. \& Ellsworth, C. C. (2007). Using podcasts and tablet PCs in computer science. In D. Dicheva, V. P. Pauca \& J. Burg (Eds.), Proceedings of the 45th annual southeast regional conference (pp. 484 - 489). New York: ACM.

Lakhal, S., Khechine, H. \& Pascot, D. (2007). Evaluation of the Effectiveness of Podcasting in Teaching and Learning. Paper presented at the World Conference on E-Learning in Corporate, Government, Healthcare, and Higher Education 2007, Quebec City, Canada.

Lane, C. (2006). UW Podcasting: Evaluation of Year One. Seattle: University of Washington.

Lazzari, M. (2009). Creative use of podcasting in higher education and its effect on competitive agency. Computers \& Education, 52(1), 27-34.

Lee, M. J. W. (2007). Reducing the effects of isolation and promoting inclusivity for distance learners through podcasting. Turkish Online Journal of Distance Education-TOJDE January 2007 ISSN 1302-6488, Volume: 8 Number: 1 Article: 7, 8(1, article 7), 85 - 104. 
Lee, M. J. W., Miller, C. \& Newnham, L. (2008). Podcasting syndication services and university students: Why don't they subscribe? The Internet and Higher Education, 12(1), 53 - 59.

Lee, M. J. W., McLoughlin, C. \& Chan, A. (2008b). Talk the talk: Learnergenerated podcasts as catalysts for knowledge creation. British Journal of Educational Technology, 39(3), 501-521.

Lyles, H., Robertson, B., Mangino, M. \& Cox, J. R. (2007). Audio podcasting in a tablet PC-enhanced biochemistry course. Biochemistry and Molecular Biology Education, 35(6), 456 - 461.

Maag, M. (2006). iPod, uPod? An emerging mobile learning tool in nursing education and students'satisfaction. In L. Markauskaite, P. Goodyear \& P. Reimann (Eds.), Proceedings of the 23rd Annual Ascilite Conference: Who's learning? Whose Technology (pp. 483 - 492). Sydney: Sydney University Press.

Malan, D. J. (2007). Podcasting computer science E-1. In Proceedings of the 38th SIGCSE technical symposium on Computer science education (pp. 389-393). Covington, Kentucky, USA: ACM.

Mathiasen, H. \& Schrum, L. (2008). Web 2.0 and Social Software: Challenges and Complexity of Communication in Education. In A. Holzinger (Ed.), HCI and Usability for Education and Work (pp. 97 - 112). Berlin, Heidelberg: Springer.

McCombs, S. \& Liu, Y. (2007). The efficacy of podcasting technology in instructional delivery. International Journal of Technology in Teaching and Learning, 3(2), 123 - 134.

McKinney, D., Dyck, J. L. \& Luber, E. S. (2008). iTunes University and the classroom: Can podcasts replace Professors? Computers \& Education, 52(3), $617-623$.

McKinney, A. A. \& Page, K. (2009). Podcasts and videostreaming: Useful tools to facilitate learning of pathophysiology in undergraduate nurse education? Nurse Education in Practice, In Press, Corrected Proof.

Muppala, J. K. \& Kong, C. K. (2007). Podcasting and its use in enhancing course content. In V. Uskov (Ed.), Proceedings of Computers and Advanced Technology in Education. Beijing.

Nathan, P. \& Chan, A. (2007). Engaging undergraduates with podcasting in a business subject. In Proceedings of the Ascilite Singapore 2007 (pp. 747 - 751). Singapore.

O’Bryan, A. \& Hegelheimer, V. (2007). Integrating CALL into the classroom: the role of podcasting in an ESL listening strategies course. ReCALL, 19, 162-180.

Ogawa, M. \& Nickles, D. (2006). Improving students perceptions in largeenrollment courses through podcasting. In Proceedings of World 
Conference on E-Learning in Corporate, Government, Healthcare, and Higher Education 2006 (pp. 250-254). Chesapeake, VA: AACE.

Ormond, P. R. (2008). Podcasting enhances learning. Journal of Computing Sciences in Colleges, 24(1), 232 - 238.

Oxford University Press. (2005). "Podcast" is the Word of the Year. Retrieved February 4, 2009, from http://www.oup.com/us/brochure/NOAD_podcast/?view=usa.

Reiser, R. A. (2001). A history of instructional design and technology: Part I: A history of instructional media. Educational Technology Research and Development, 49(1), 53 - 64.

Ribchester, C., France, D. \& Wheeler, A. (2008). Podcasting: A Tool for Enhancing Assessent Feedback? In E. O'Doherty (Ed.), Education in a Changing Environment: Conference Book, Volume 4. Santa Rosa, CA: Informing Science.

Saeed, N. \& Yang, Y. (2008). Incorporating blogs, social bookmarks, and podcasts into unit teaching. In Proceedings of the tenth conference on Australasian computing education - Volume 78 (pp. 113-118). Wollongong, NSW, Australia: Australian Computer Society, Inc.

Smith, G. \& Fidge, C. (2008). On the efficacy of prerecorded lectures for teaching introductory programming In Proceedings of the tenth conference on Australasian computing education - Volume 78 (pp. 129136 ). Wollongong, NSW, Australia Australian Computer Society, Inc.

Socialdemokraterne. (2007). Bedre vilkår for studerende. Studiepolitisk oplæg fra Socialdemokraterne. Frederiksberg: Socialdemokraterne.

Tynan, B. \& Colbran, S. (2006). Podcasting, student learning and expectations. In L. Markauskaite, P. Goodyear \& P. Reimann (Eds.), Proceedings of the 23rd Annual Ascilite Conference: Who's Learning? Whose Technology (pp. 825-883). Sydney.

Vogele, C. \& Gard, E. T. (2006). Podcasting For Corporations And Universities: Look Before You Leap. Journal of Internet Law, 10(4), 3 13.

\section{Appendix A: Kilder}

Materialet til denne undersøgelse er fremskaffet ved søgning efter artikler om "podcast" og "podcasting" i 10 internationale akademiske, elektroniske databaser:

ACM Digital Library, http://www.acm.org/dl/.

Cambridge Journals Online, http://journals.cambridge.org/action/home.

Elsevier ScienceDirect, http://www.sciencedirect.com/science/journals. 
Emerald, http://www.emeraldinsight.com/Insight/.

Ingenta, http://www.ingentaconnect.com/.

JSTOR, http://www.jstor.org/cgi-bin/jstor/gensearch.

Oxford Journals Online, http://www.oxfordjournals.org/.

SAGE Journals, http://online.sagepub.com.

SpringerLink, http://link.springer.de/search.htm.

Wiley Inter Science,

http://www3.interscience.wiley.com/journalfinder.html.

Som supplement er foretaget søgninger efter "podcast" og "podcasting" i kombinationer med "learning", "evaluation", "university" og "project" i Google Scholar, http://scholar.google.com/. I hvert af søgeresultaterne er de første 200 poster gennemgået, og for poster, som er skønnet relevante, er også citationerne ("citeret af") undersøgt.

Endelig er inddraget en samling rapporter fra Duke University, som var et af de første universiteter til at benytte podcasting i stor målestok. Dermed er søgt inddraget eksempler på studier af podcast-anvendelse over længere tid end de mange studier af ganske korte forløb, som dominerer materialet.

Materialeindsamlingen er foregået i anden halvdel af januar, 2009.

\section{Appendiks B: Analyseskema}

Alle udvalgte artikler er gennemgået med henblik på besvarelse af flest mulige af følgende spørgsmål:

Kilde:

Land:

Uddannelsesniveau:

Fag:

Undervisningsform:

Antal deltagere:

Aldersfordeling:

Forsøgets varighed:

Materialets omfang: 
Varighed af podcasts:

Teknologi og medievalg:

Adgang til/distribution af materialer:

Formål med podcasts:

Konkret indhold:

Integration i undervisningen:

Studenterinvolvering:

Brugssituation for studerende:

Omfang af anvendelse:

Undersøgelsens metode:

Evalueringsform:

Resultater: 